\title{
PHARMACOLOGY OF THE
} ADRENOCEPTORS AND CHOLINOCEPTORS OF THE $\mathrm{BC}_{3} \mathrm{H} 1$ NONFUSING MUSCLE CELL LINE

\section{JEAN-PIERRE MAUGER, ANNE-MARIE MOURA \& MANUEL WORCEL}

INSERM Unité 7, Physiologie \& Pharmacologie, Hôpital Necker, 161, rue de Sèvres, 75015

Paris, France

1 We have studied the action of different transmitters on the transmembrane ${ }^{42} \mathrm{~K}$ or ${ }^{86} \mathrm{Rb}$ efflux from tissue cultures of the $\mathrm{BC}_{3} \mathrm{H} 1$ muscle cell line.

2 The effect of catecholamines and carbachol $(\mathrm{CCh})$ on the isotope efflux rate was measured by addition of the drugs at different times during the washout.

3 Noradrenaline (NA), phenylephrine (Phe), isoprenaline (Iso) and CCh increased ${ }^{42} \mathrm{~K}$ and ${ }^{86} \mathrm{Rb}$ efflux rate in a dose-dependent manner.

4 The action of NA seems to be due exclusively to the stimulation of $\alpha$-receptors, since its effect was blocked by phentolamine but not by propranolol. The effects of Iso on the ${ }^{86} \mathrm{Rb}$ efflux were inhibited by propranolol. The $\beta$-receptors in the $\mathrm{BC}_{3} \mathrm{H} 1$ cells seem to be of the $\beta_{2}$-type since they are stimulated by Iso and insensitive to NA.

5 The effect of $\mathrm{CCh}$ was blocked by (+)-tubocurarine but not by atropine. This result confirms the presence of nicotinic receptors in $\mathrm{BC}_{3} \mathrm{H} 1$ cells.

\section{Introduction}

Schubert, Harris, Devine \& Heinemann (1974), separated several cell lines from a brain tumour induced in mice by the injection of nitrosoethylurea (Ivankovic \& Druckrey, 1968). One of these cell lines, called $\mathrm{BC}_{3} \mathrm{H} 1$, defined as a non-fusing muscle cell line has many characteristics of smooth muscle. In the confluent state the cells are elongated, contain thick and thin filaments and their membranes show numerous vesicles closely resembling the stable structures observed by Gabella (1973) in different smooth muscles. The cells have sometimes been observed to contract spontaneously. The cell membrane is excitable, the iontophoretic application of acetylcholine producing a rapid depolarization. On the other hand, noradrenaline (NA) has a hyperpolarizing effect. However, impalement of these cultured cells is diffcult, making a pharmacological analysis of the membrane response to chemical mediators and drugs rather cumbersome.

The purpose of the present work was to study the membrane response of the $\mathrm{BC}_{3} \mathrm{H} 1$ cells by a different approach. We have examined the effects of catecholamines, carbachol and some of their antagonists on ${ }^{86} \mathrm{Rb}$ and ${ }^{42} \mathrm{~K}$ effluxes. It has been observed previously that molecules which have a depolarizing or a hyperpolarizing effect increase $\mathrm{K}^{+}$permeability either primarily or secondarily (Durbin \& Jenkinson,
1961; Burgen \& Spero, 1968, Worcel \& Hamon, 1976). The results obtained indicate that the $\mathrm{BC}_{3} \mathrm{H} 1$ cells have $\alpha$ - and $\beta$-adrenoceptors. The latter seem to correspond to the $\beta_{2}$-type usually found in mammalian smooth muscle (Lands, Arnold, McAuliff, Luduena \& Brown, 1967). On the other hand, there was also a response, unusual in this type of tissue, to the nicotinic cholinoceptor blocker, $(+)$-tubocurarine. This drug blocked the effect of carbachol on ${ }^{86} \mathrm{Rb}$ and ${ }^{42} \mathrm{~K}$ effluxes confirming the presence of nicotinic receptors in these cells.

\section{Methods}

\section{Tissue culture}

The cloned muscle cell line was grown in Dulbecco modified Eagle's medium (Vogt \& Dulbecco, 1963) containing $10 \%$ foetal calf serum at $37^{\circ} \mathrm{C}$ in an atmosphere of $12 \% \mathrm{CO}_{2}$ and $88 \%$ air. The line was maintained in the exponential phase of growth by passage every 4 days. The cells were resuspended in $0.25 \%$ Viokase in Dulbecco modified Eagle's medium, centrifuged and resuspended in the growth medium. They were plated in plastic tissue culture dishes at $10^{3}$ cells $/ \mathrm{cm}^{2}$. The cells used for efflux studies were grown on $10.5 \times 50 \mathrm{~mm}$ glass slides in $90 \mathrm{~mm}$ diameter 
a

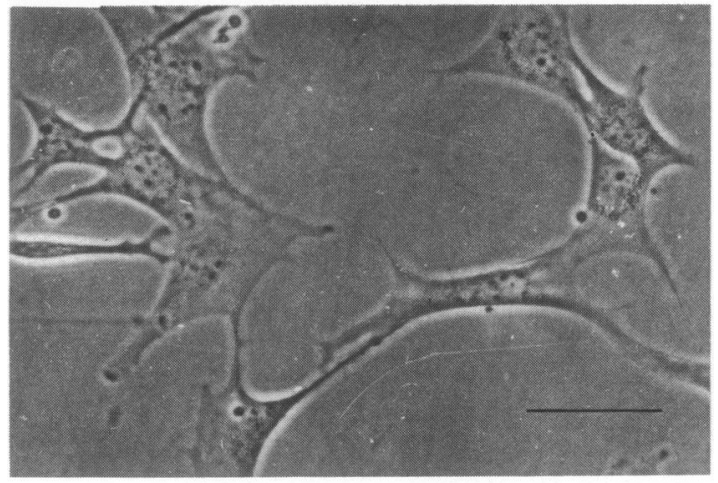

b

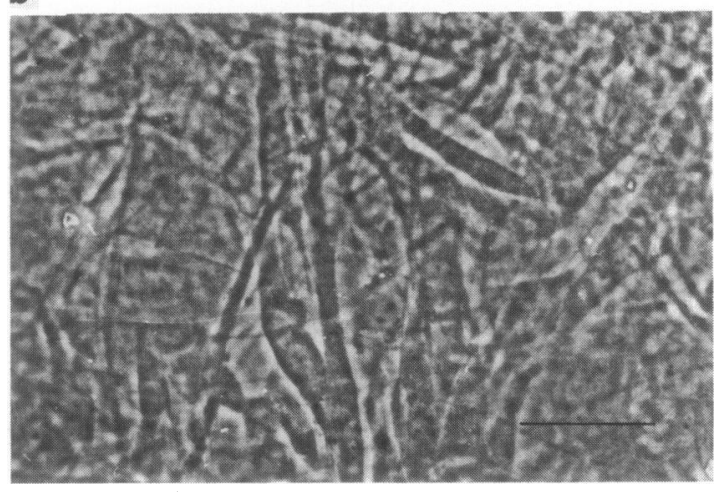

Figure 1 Morphological characteristics of the $\mathrm{BC}_{3} \mathrm{H} 1$ cells used in this study. (a) Exponential phase; (b) culture 1 week after reaching confluency. The bar represents $50 \mu \mathrm{m}$. 


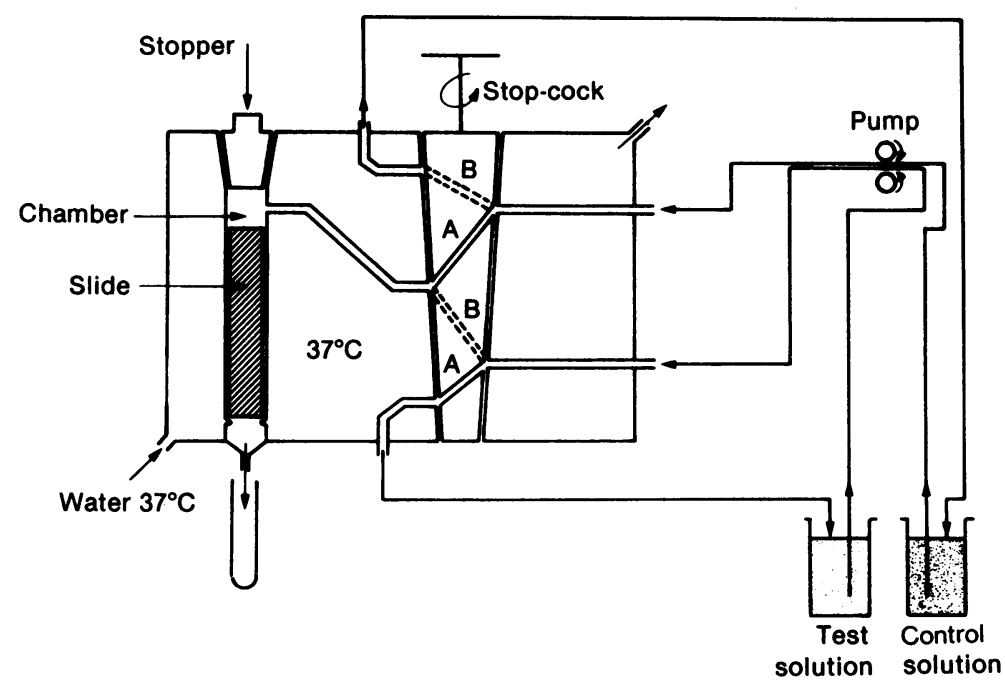

Figure 2 Schematic representation of the glass apparatus used for the efflux experiments. A slide with the cultured cells loaded with ${ }^{42} \mathrm{~K}$ or ${ }^{86} \mathrm{Rb}$ was placed in the chamber $(2 \mathrm{ml}$ volume). The chamber was perfused with either a physiological saline solution (PSS) alone (stop-cock in position A) or with the PSS containing the drug tested (stop-cock in position B). The solutions could be changed without any change in the flow, which was maintained constant at $7 \mathrm{ml} / \mathrm{min}$ by a roller pump. The effluent was collected at fixed times in test tubes for counting. The chamber and the incoming solutions were maintained at $37^{\circ} \mathrm{C}$ by circulating water.

dishes. The medium was changed every 2 days. The cells were usually used 1 week after reaching confluence, except in those cases indicated in the results section (Figure 1).

\section{Measurement of ${ }^{42} \mathrm{~K}$ and ${ }^{86} \mathrm{Rb}$ fluxes}

The slide with the cells attached to one side was removed from the dish, rinsed once and incubated for at least $120 \mathrm{~min}$ in a physiological saline solution (PSS) with the following composition (mM): $\mathrm{Na}^{+}$ 136.9, $\mathrm{K}^{+} 5.9, \mathrm{Ca}^{2+} 2.5, \mathrm{Mg}^{2+} 1.2, \mathrm{HCO}_{3}^{-} 15.5$, $\mathrm{H}_{2} \mathrm{PO}_{4}^{-} 1.2, \mathrm{Cl}^{-} 133.5$ and glucose 11.5. The solutions contained 10 to $20 \mu \mathrm{Ci} / \mathrm{ml}$ of ${ }^{42} \mathrm{~K}$ or ${ }^{86} \mathrm{Rb}$. When the latter isotope was used, all $\mathrm{K}^{+}$in the loading and perfusing solutions was replaced by $\mathbf{R b}^{+}$. During the loading period and the washout, PSS was gassed with a $95 \% \mathrm{O}_{2}$ and $5 \% \mathrm{CO}_{2}$ mixture. After loading, the slide was placed in a chamber maintained at a constant temperature (Figure 2) after rinsing in PSS for not more than $60 \mathrm{~s}$ in order to reduce the amount of isotope sticking to the surface. The slide was then perfused continuously with the PSS at a constant flow of $7 \mathrm{ml} / \mathrm{min}$ with a roller pump. The volume of the chamber being $2 \mathrm{ml}$, the complete replacement of the medium around the cells was achieved within one minute. A four way stop-cock allowed solutions to be changed without interruption of the perfusion at any time. The entire effluent was collected every min- ute or every 2 min and counted in a well $\gamma$-counter. At the end of the experiment, the radioactivity remaining in the cells was counted. A desaturation curve was calculated by adding in a reverse order the washout curve to the radioactivity remaining in the cells at the end of the experiment (Hamon, Papadimitriou \& Worcel, 1976).

\section{Drugs}

All salts were reagent grade. (-)-Phenylephrine hydrochloride, (-)-noradrenaline hydrochloride, (-)-isoprenaline bitartrate, $( \pm)$-propranolol hydrochloride, carbamylcholine chloride and (+)-tubocurarine chloride were purchased from Sigma and phentolamine hydrochloride from Ciba-Geigy; Viokase, Dulbecco modified Eagle's medium and foetal calf serum from Gibco.

\section{Statistical methods}

Means and standard error of the mean have been calculated assuming a normal distribution and allowing for the small size of the samples (Schwartz, 1963).

\section{Results}

${ }^{42} \mathrm{~K}$ and ${ }^{86} \mathrm{Rb}$ turnovers were analysed in terms of 


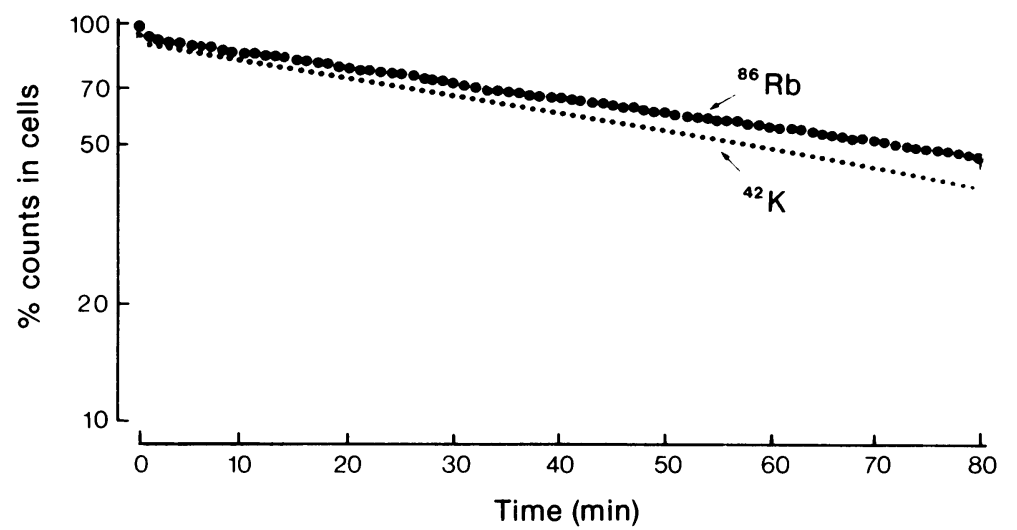

Figure 3 Desaturation curves for ${ }^{86} \mathrm{Rb}$ and ${ }^{42} \mathrm{~K}$ from $\mathrm{BC}_{3} \mathrm{H} 1$ cultures in the confluent state. After a fast initial washout, the desaturation of both isotopes resolves in a single exponential. Single experiments are represented for clarity. The difference between the mean efflux rate (see text) is not significant: $\mathrm{r}_{{ }^{2} \mathrm{~K}}=0.0083 \pm 0.0006 / \mathrm{min}(n=7)$ and $\mathrm{r}_{\mathrm{B}} \mathrm{Rb}=0.0092 \pm 0.0009 / \mathrm{min}(n=18)$. The ordinate scale represents the percentage counts left in the tissue at a given time after washout. The abscissa scale represents the time of washout.

the rate coefficient which is calculated by the expression:

$$
r=\frac{A_{1}-A_{2}}{\frac{A_{1}+A_{2}}{2}\left(t_{2}-t_{1}\right)}
$$

where $r$ is the rate coefficient, $A_{1}$ and $A_{2}$ are two points in the desaturation curve at time $t_{1}$ and $t_{2}$. The rate coefficient decreased rapidly and continuously during the first $5 \mathrm{~min}$, as a consequence of the washout of the isotope adsorbed on to the surface of cells and slides and to diffusion from the extracellular space. After $5 \mathrm{~min}$, the rate became constant and probably represented the membrane-limited efflux from the cells (Worcel \& Hamon, 1976).

Preliminary experiments were peformed with ${ }^{42} \mathrm{~K}$ as an isotope, but the determination of the efflux curves was complicated by the fact that as a consequence of the short half-life of ${ }^{42} \mathrm{~K}$, the radioactivity in the washout and slides was very low, especially after prolonged experiments. As a result ${ }^{42} \mathrm{~K}$ was replaced by ${ }^{86} \mathrm{Rb}$, since the longer half-life of ${ }^{86} \mathrm{Rb}$ makes its handling easier. We have compared the efflux rates of the $\mathrm{BC}_{3} \mathrm{H} 1$ cells for ${ }^{42} \mathrm{~K}$ and ${ }^{86} \mathrm{Rb}$ (Figure 3). At the end of the exponential growth phase, the mean efflux rate coefficients for both isotopes were similar: $0.0083+0.0006 / \min (n=7)$ for ${ }^{42} \mathrm{~K}$ and $0.0092 \pm 0.0009 / \mathrm{min}(n=18)$ for ${ }^{86} \mathrm{Rb}$. It has been shown that $\mathrm{Rb}^{+}$behaves like $\mathrm{K}^{+}$with respect to ionic channels and the $\mathrm{Na}^{+}-\mathrm{K}^{+}$pump. Widdicombe (1977) observed that $\mathrm{Rb}^{+}$can inhibit the ouabain-sensitive uptake of $\mathrm{K}^{+}$in the guinea-pig taenia coli smooth muscle. The pump has the same affinity for both $\mathrm{Rb}^{+}$and $\mathrm{K}^{+}$. Similarly, $\mathrm{Rb}^{+}$reduces the $\mathrm{K}^{+}$passive uptake indicating that these ions pass through the same channel in the cell membrane. Similar interactions between $\mathrm{Rb}^{+}$and $\mathrm{K}^{+}$fluxes have been reported in red blood cells (Sachs \& Welt, 1967).

\section{Effects of noradrenaline on the efflux rate}

The amine produced an increase in the ${ }^{86} \mathrm{Rb}$ efflux rate at concentrations higher than $10^{-7} \mathrm{M}$. In preliminary experiments, we determined the times of exposure necessary to attain the maximal effects of a given concentration and the intervals required to reduce tachyphylaxis to NA to a minimum. The doses of NA were administered over $6 \mathrm{~min}$ and the slides washed for $20 \mathrm{~min}$ before being superfused with another dose of the drug. Increasing concentrations of NA applied under these conditions produced a dose-dependent enhancement of ${ }^{86} \mathrm{Rb}$ efflux rates (Figure 4). The maximum effects were attained only after at least $3 \mathrm{~min}$ exposure to the drug. This delay seemed to be due at least partly, to diffusion delay in the perfusion chamber since it was longer than the time needed to obtain a hyperpolarization following iontophoretic application (Schubert et al., 1974). In all cases, the effects of NA were faster at higher concentrations, the time to peak being shorter at these levels.

Dose-response curves to NA were obtained at the exponential and confluent stages of growth of the cultures. The results obtained were similar, the $E_{50}$ value for NA during the exponential phase (before confluence) was $3.6 \times 10^{-7} \mathrm{M}$. One or two weeks later, the $\mathrm{ED}_{50}$ was still $3.8 \times 10^{-7} \mathrm{M}$ (Figure 5). These results indicate that there was no variation in 


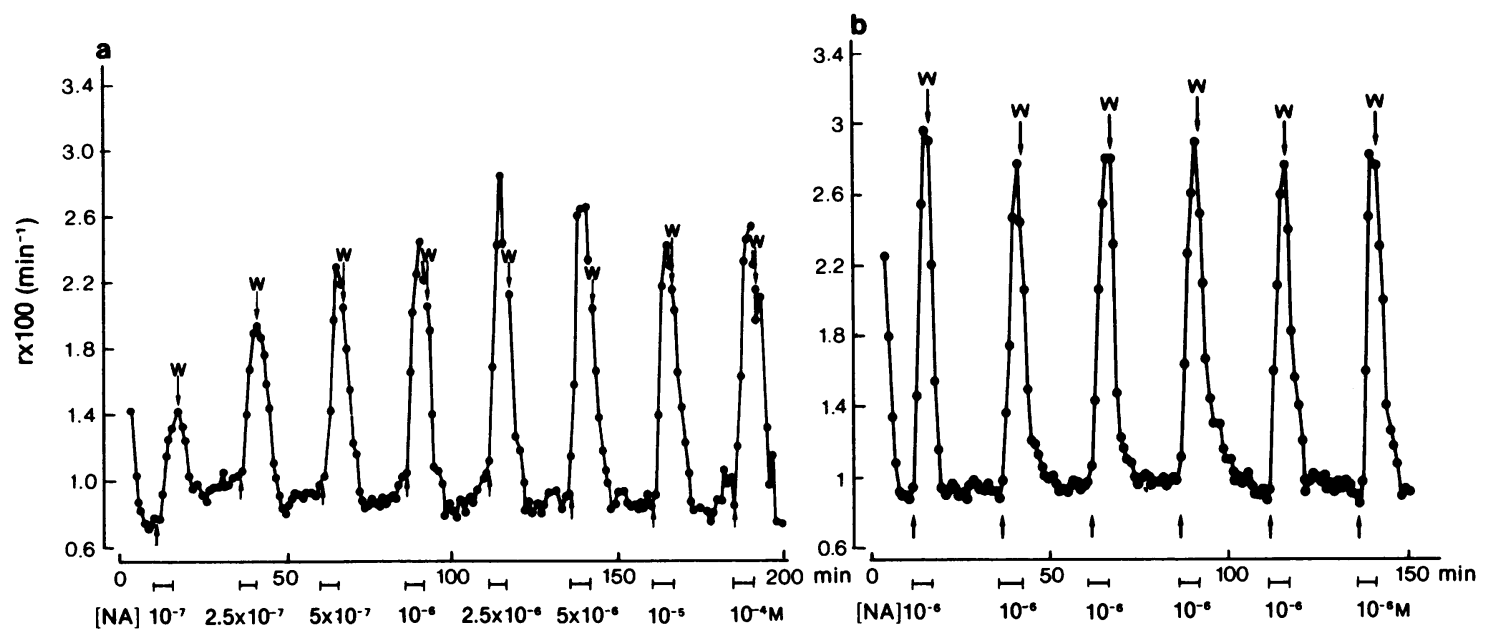

Figure 4 (a) Effect of noradrenaline (NA) on the ${ }^{86} \mathrm{Rb}$ efflux rate from $\mathrm{BC}_{3} \mathrm{H} 1$ cells in the confluent state. The arrows at the bottom indicate the beginning of the perfusion of the slide with the physiological salt solution (PSS) containing NA. W indicates the return to the PSS alone. Increasing concentrations of NA enhanced the efflux rate coefficient in a dose-dependent manner. A plateau was attained with concentrations higher than $2.5 \times 10^{-6} \mathrm{M}$ NA. A single experiment is shown for clarity; 6 similar experiments were performed. The average curve is represented in Figure 5. (b) Effect of repeated exposure of the $\mathrm{BC}_{3} \mathrm{H1}$ to $10^{-6} \mathrm{M} \mathrm{NA}$, a concentration that produces a submaximal increase in the ${ }^{86} \mathrm{Rb}$ efflux. At this concentration and when the intervals between administration are longer than 20 min, no desensitization occurred. $r$ is the rate coefficient (see text). Time zero indicates the beginning of the washout.

the response to NA during the differentiation of the cells. All the following experiments were performed with cultures one or two weeks after confluence.

\section{Characterization of adrenoceptors}

The action of NA was tested in the presence of different concentrations of phentolamine. In the following experiments the antagonists were added to the PSS. At a concentration of $10^{-6} \mathrm{M}$ phentolamine displaced the NA dose-response curves to the right (Figure 6a). The difference in the maximum response should be disregarded given the variability of the results. With phenylephrine (Phe), a specific $\alpha$-agonist, it was observed that phentolamine $10^{-6} \mathrm{M}$ still produced the same qualitative and quantitative effects as NA (Figure $6 \mathrm{~b}$ ). These findings suggested that both Phe and even NA act exclusively on $\alpha$-adrenoceptors. The latter possibility was confirmed further by the action of higher doses of phentolamine which at $5 \times 10^{-5} \mathrm{M}$ practically suppressed the effects of NA (Figure 6a). The preferential stimulation of $\alpha$-adrenoceptors by NA was confirmed by the experiments performed in the presence of propranolol. This antagonist did not affect NA dose-response curves at concentrations of $10^{-6} \mathrm{M}$ and $5 \times 10^{-5} \mathrm{M}$.

The preceding experiments indicated that the $\beta$-adrenoceptors in $\mathrm{BC}_{3} \mathrm{H} 1$ cells are not stimulated by NA. The $\beta$-agonist isoprenaline increased ${ }^{86} \mathrm{Rb}$ efflux in a dose-dependent manner. This effect was blocked by $10^{-6} \mathrm{M}$ propranolol. At this concentration, the antagonist shifted the curves to the right with a dose-ratio of 10 (Figure 7). On the other hand, phentolamine at $10^{-6} \mathrm{M}$ did not modify the response to isoprenaline. This confirmed the presence, in these cells of $\beta$-adrenoceptors that were activated by isoprenaline but not by NA. Consequently these receptors would correspond to the $\beta_{2}$-type as described by Lands et al. (1967), found especially in smooth muscle cells, and activated by the following series of agonists: isoprenaline $>$ adrenaline $\gg$ noradrenaline, as opposed to $\beta_{1}$-receptors chiefly found in cardiac sites, activated by the following series: isoprenaline $>$ adrenaline $=$ noradrenaline.

\section{Effects of carbamylcholine $(C C h)$ on the ${ }^{86} R b$ efflux rate}

Iontophoretic application of acetylcholine to the $\mathrm{BC}_{3} \mathrm{H} 1$ cells results in membrane depolarization (Schubert et al., 1974). This confirms the results of Patrick, McMillan, Wolfson \& O'Brien (1977) who have shown that $\alpha$-bungarotoxin binds specifically to $\mathrm{BC}_{3} \mathrm{H} 1$ cell membranes. We first tested the action of $\mathrm{CCh}$ on the ${ }^{86} \mathrm{Rb}$ efflux in the same clone used for all the previous experiments. Surprisingly the agonist 


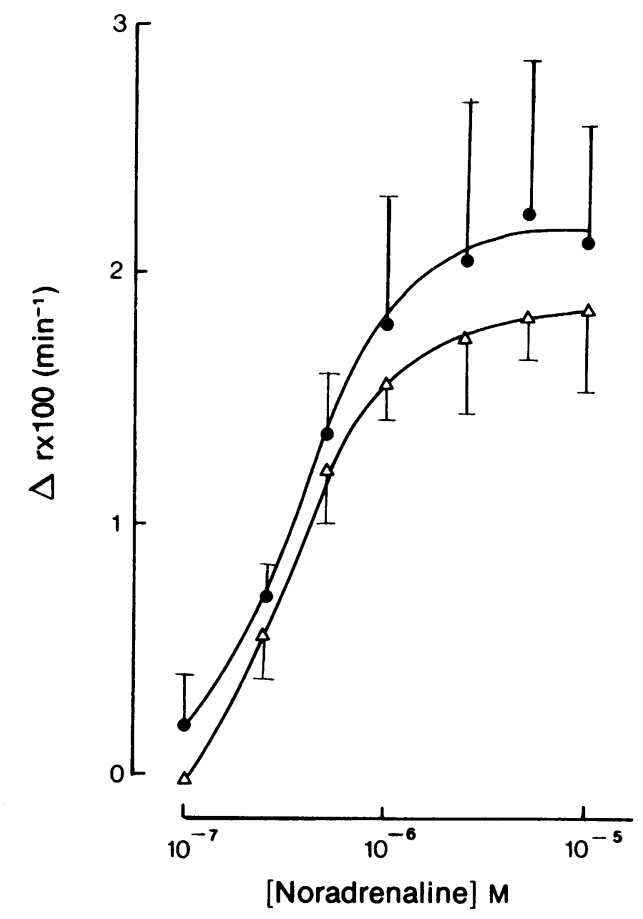

Figure 5 Log dose-effect curves of noradrenaline (NA) on cells 1 week after reaching confluence (O) or in the logarithmic phase of growth $(\Delta) r$ is the efflux rate coefficient of ${ }^{86} \mathrm{Rb}$. Each point is the mean of at least 4 experiments. Vertical bars represent s.e. means.

did not modify the efflux rates even at concentrations as high as $10^{-4} \mathrm{M}$. Positive results were obtained only with the $\mathrm{BC}_{3} \mathrm{H} 1$ clone used by Patrick et al. (1977). $\mathrm{CCh}$ increased the efflux rate constant of ${ }^{86} \mathrm{Rb}$ from these cells. The response was more rapid than with NA, phenylephrine or isoprenaline, the maximum ${ }^{86} \mathrm{Rb}$ efflux rate being attained within the first $2 \mathrm{~min}$ of exposure to the drug. CCh produced a dose-dependent increase in ${ }^{86} \mathrm{Rb}$ efflux with an $\mathrm{ED}_{50}$ of $4 \times 10^{-6} \mathrm{M}$. This effect was not blocked by $10^{-6} \mathrm{M}$ atropine. The same concentration of (+)-tubocurarine had a non-competitive blocking effect of CCh action (Figure 8). Our finding confirmed previous results indicating that this clone of the $\mathrm{BC}_{3} \mathrm{H} 1$ cell line possesses nicotinic cholinoceptors.

\section{Discussion}

The purpose of this work was to examine the membrane response of the $\mathrm{BC}_{3} \mathrm{H} 1$ cells to different putative transmitters and some of their analogues and antagonists. To gauge the membrane effects we have studied the action of these substances on ${ }^{86} \mathrm{Rb}$ and ${ }^{42} \mathrm{~K}$ efflux rates. Depolarization of the cell membrane activates an electrically dependent $\mathrm{K}^{+}$conductance in smooth, striated and cardiac muscles, as well as in nervous tissue (Ginsborg, 1967). Furthermore the hyperpolarization induced by NA in other excitable tissues appears to be at least partly due to a primary increase in the membrane conductance to $\mathrm{K}^{+}$as shown by Bülbring \& Tomita (1969) in guinea-pig taenia coli. Direct evidence for such an action has been previously obtained by Jenkinson \& Morton $(1965 ; 1967)$ who found that NA doubled the rate of ${ }^{42} \mathrm{~K}$ loss from depolarized taenia coli. Consequently, it might be expected that cell depolarization would result in an increase in $\mathrm{K}^{+}$or $\mathrm{Rb}^{+}$efflux rates and that hyperpolarization would be frequently, but not always, associated with a primary enhancement of these rates. However, our experiments were designed to quantify the membrane effects of agonists and antagonists using ${ }^{86} \mathrm{Rb}$ and ${ }^{42} \mathrm{~K}$ effluxes as tools.

The present results show that $\mathrm{BC}_{3} \mathrm{H} 1$ cells possess $\alpha$-adrenoceptors that are activated by NA and Phe and inhibited by phentolamine. Isoprenaline stimulated ${ }^{86} \mathrm{Rb}$ efflux from these cells, this effect being blocked by propranolol. Conversely, the NA effect on ${ }^{86} \mathrm{Rb}$ efflux was not modified by propranolol. These findings suggest that the $\beta$-receptors present in the $\mathrm{BC}_{3} \mathrm{H} 1$ line are probably of the $\beta_{2}$-type (Lands et al., 1967) since they are stimulated by isoprenaline and apparently unaffected by NA up to a concentration of $10^{-5} \mathrm{M}$. Schubert, Tarikas \& La Corbiere (1976) studied the effects of NA at a concentration of $10^{-4} \mathrm{M}$ in the presence of $10^{-3} \mathrm{M}$ theophylline on the cyclic AMP levels of fusing and non-fusing muscle cell lines. At these high concentrations NA has a very moderate effect on $\mathrm{BC}_{3} \mathrm{H} 1$ cells, much smaller than the stimulatory action observed in skeletal muscle myoblasts and myotubes.

Responses to cholinoceptor agonists were obtained only in the clone of the $\mathrm{BC}_{3} \mathrm{H} 1$ line used by Patrick, et al. (1977). There is no explanation yet to account for the failure of certain clones of $\mathrm{BC}_{3} \mathrm{H} 1$ lines to give such responses. ${ }^{86} \mathrm{Rb}$ effluxes were stimulated in a dose-dependent manner by $\mathrm{CCh}$. Since acetylcholine produced a depolarization of these cells, the increase in ${ }^{86} \mathrm{Rb}$ efflux may be related to an increase in membrane permeability to $\mathrm{K}^{+}$secondary to the change in membrane potential. The effect of the cholinoceptor agonist on ${ }^{86} \mathbf{R b}$ efflux was not modified by atropine in concentrations up to $10^{-6} \mathrm{M}$. On the other hand $(+)$-tubocurarine produced a clearcut displacement of CCh dose-response curves. Our findings are consistent with the results of Patrick et al. (1977) who showed that these cells bound $\alpha$-bungarotoxin and that this binding was preferentially displaced by ( + )-tubocurarine and only very weakly by atropine, hexamethonium or decamethonium. These results in- 

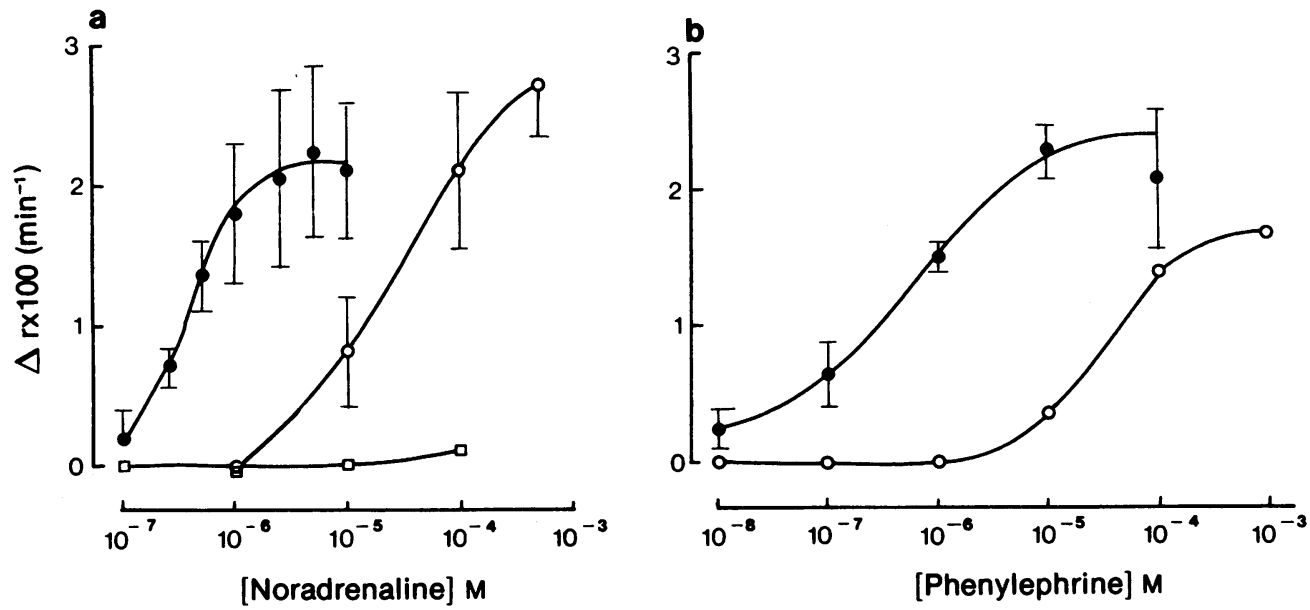

Figure 6 (a) Log dose-effect curves for noradrenaline (NA) on cells in the stationary phase in the absence (O) (4 experiments) or in the presence of $10^{-6} \mathrm{M}(O)$ (3 experiments) or $5 \times 10^{-5} \mathrm{M}(\square)(1$ experiment) phentolamine. (b) Log dose-effect curves for phenylephrine on cells in the stationary phase in the absence (0) (4 experiments) or in the presence of $10^{-6} \mathrm{M}$ phentolamine (O) (1 experiment). $r$ is the efflux rate coefficient of ${ }^{86} \mathrm{Rb}$. Vertical bars represent s.e. means.

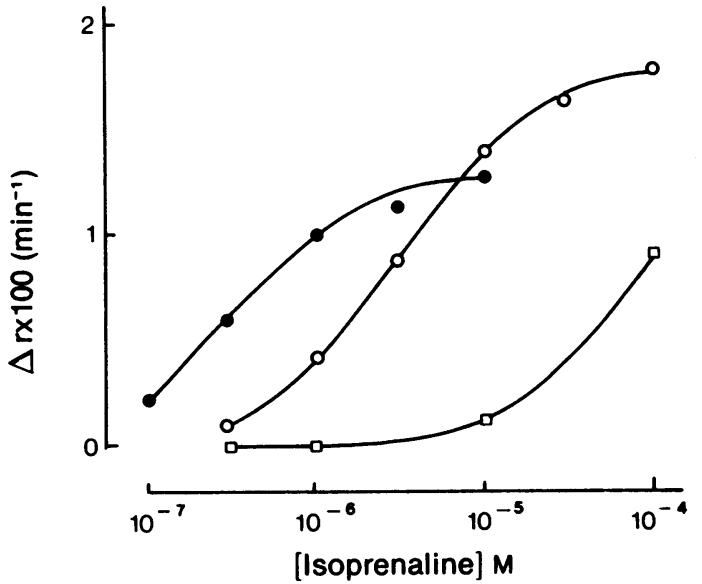

Figure 7 Log dose-effect curves for isoprenaline on cells in the stationary phase in the absence $(0)$ or in the presence of $10^{-6} \mathrm{M}(\mathrm{O})$ or $5 \times 10^{-\mathrm{B}} \mathrm{M}$ ( $\square$ ) propranolol. $r$ is the efflux rate coefficient of ${ }^{86} \mathrm{Rb}$. Each point is the mean of 2 experiments. Since propranolol did not have any effect on NA dose-effect curves, this result suggests that these cells have $\beta_{2}$-receptors (see text).

dicate that the cholinoceptors of the $\mathrm{BC}_{3} \mathrm{H} 1$ line are nicotinic.

The $\mathrm{BC}_{3} \mathrm{H} 1$ cell line was originally described as a smooth muscle cell line (Schubert et al., 1974) on the grounds of morphological, physiological and biochemical properties. These cells resemble in their differentiated state other smooth muscle cells in culture

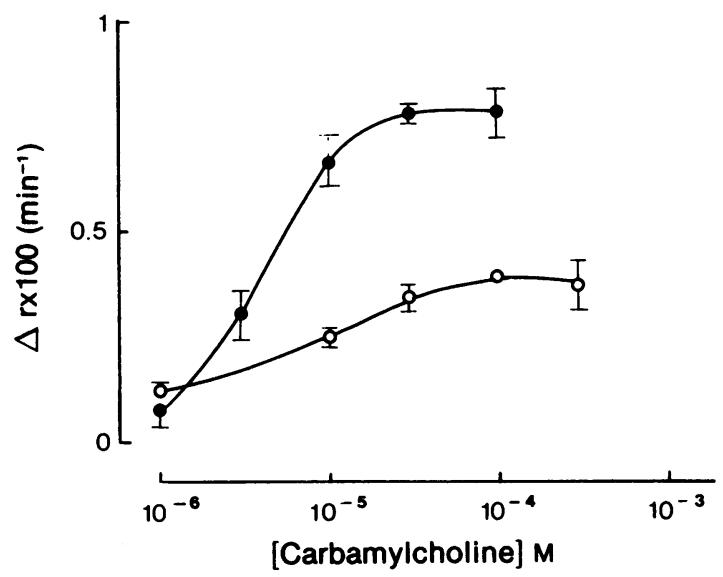

Figure 8 Log dose-effect curve for carbamylcholine on cells in the stationary phase in the absence (O) and presence of $10^{-6} \mathrm{M}(+)$-tubocurarine (O). $r$ is the efflux rate coefficient of ${ }^{86} \mathrm{Rb}$. Each point is the mean of 3 experiments. Vertical bars represent s.e. means. The $\mathrm{BC}_{3} \mathrm{H} 1$ cells have nicotinic cholinoceptors (see text).

as described previously by Chamley, Campbell \& Burnstock (1974), Campbell, Chamley \& Burnstock (1974) and Mauger, Worcel, Tassin \& Courtois (1975). They are elongated, disposed in parallel bundles running in perpendicular directions when in multilayers. Electronmicrographs shown a few caveolae in the cell membrane (Schubert et al., 1974), thick and thin fila- 
ments and no sarcomeres or $\mathrm{Z}$ lines. However, these excitable non-fusing muscle cells do not behave pharmacologically as typical smooth muscle cells. On one hand $\alpha$ - and $\beta_{2}$-adrenoceptors have been described in both vascular and visceral smooth muscles. On the other hand, the presence of nicotinic receptors makes them rather atypical since to our knowledge only muscarinic receptors have been observed in mammalian smooth muscles. In any case, the $\mathrm{BC}_{3} \mathrm{H} 1$ cell

\section{References}

BÜLBRING, E. \& TOMITA, T. (1969). Increase of membrane conductance by adrenaline in the smooth muscle of guinea-pig taenia coli. Proc. Roy. Soc. B., 172, 89-102.

BURGEN, A.S.V. \& SPERO, L. (1968). The action of acetylcholine and other drugs on the efflux of potassium and rubidium from smooth muscle of guinea-pig intestine. Br. J. Pharmac., 34, 99-115.

CAMPBELL, G.R., CHAMLEY, J.H. \& BURNSTOCK, G. (1974). Development of smooth muscle cells in tissue culture. J. Anat., 117, 295-312.

CHAMLEY, J.H., CAMPBELL, G.R. \& BURNSTOCK, G. (1974). Dedifferentiation, redifferentiation and bundle formation of smooth muscle cells in tissue culture: the influence of cell number and nerve fibres. J. Embryol. exp. Morph., 32, 297-323.

DURBIN, R.P. \& JENKINSON, D.H. (1961). The effect of carbachol on the permeability of depolarized smooth muscle to inorganic ions. J. Physiol., 157, 74-89.

GABELLA, G. (1973). Fine structure of smooth muscles. Phil. Trans. R. Soc. B., 265, 7-16.

GINSBORG, B.L. (1967). Ion movements in junctional transmission. Pharmac. Rev., 19, 289-316.

HAMON, G., PAPADIMITRIOU, A. \& WORCEL, M. (1976). Ionic fluxes in rat uterine smooth muscle. J. Physiol., 254, 229-243.

IVANKOVIC, S. \& DRUKREY, H. (1968). Transplazentare erzeugung maligner Tumoren des Nerven Systems. I. Athyl-nitroso-Harnstoff (ANH) an BDIX Ratten. $Z$. Krebsforsh., 71, 320.

JENKINSON, G.H. \& MORTON, I.K.M. (1965). Effects of noradrenaline and isoprenaline on the permeability of depolarized intestinal smooth muscle to inorganic ions. Nature, Lond., 205, 505-506.

JENKINSON, D.H. \& MORTON, I.K.M. (1967). The effect of noradrenaline on the permeability of depolarized intestinal smooth muscle to inorganic ions. J. Physiol., 188, 373-386. line may be a suitable model to study interactions between adrenoceptors and cholinoceptors in different stages of cell differentiation.

The authors are indebted to Drs J. Patrick and D. Schubert for the generous supply of the $\mathrm{BC}_{3} \mathrm{Hl}$ line. This work was supported by a grant from the D.G.R.S.T. France (No. 75.7.0948).

LANDS, A.M., ARNOLD, A., McAULIFF, J.P., LUDUENA, F.P. \& BROWN, T.G. Jr. (1967). Differentiation of receptor systems activated by sympathomimetic amines. Nature, Lond., 214, 597-598.

MAUGER, J.P., WORCEL, M., TASSIN, J. \& COURTOIS, Y. (1975). Contractility of smooth muscle cells of rabbit aorta in tissue culture. Nature, Lond., 255, 337-338.

PATRICK, J., McMILLAN, J., WOLFSON, H. \& O'BRIEN, J.C. (1977). Acetylcholine receptor metabolism in a non-fusing muscle cell line. J. biol. Chem., 252, 2143-2153.

SACHS, J.R. \& WELT, L.G. (1967). The concentration dependence of active potassium transport in the human red blood cell. J. clin. Invest., 46, 65-76.

SCHUBERT, D., HARRIS, A.J., DEVINE, C.E. \& HEINEMANN, S. (1974). Characterization of a unique muscle cell line. J. cell Biol., 61, 398-413.

SCHUBERT, D., TARIKAS, H. \& LA CORBIERE, M. (1976). Neurotransmitter regulation of adenosine $3^{\prime}, 5^{\prime}$-monophosphate in clonal nerve, glia and muscle cell lines. Science, N.Y. 192, 471-472.

SCHWARTZ, D. (1963). Les petits échantillons. In Méthodes Statistiques à lUsage des Médecins et Biologistes. pp. 151-162. Paris: Editions Médicales Flammarion.

VOGT, M. \& DULBECCO, R. (1963). Steps in the neoplastic transformation of hamster embryo cells by polyoma virus. Proc. natn. Acad. Sci. U.S.A., 49, 171-182.

WIDDICOMBE, J.H. (1977). Ouabain-sensitive ion fluxes in the smooth muscle of the guinea-pig's taenia coli. $J$. Physiol., 266, 235-254.

WORCEL, M. \& HAMON, G. (1976). Changes in ionic fluxes in uterine smooth muscle induced by carbachol. Physiology of Smooth Muscle. ed. Bülbring, E. \& Shuba, M.F. pp. 339-345. New York: Raven Press.

(Received December 8, 1977. Revised April 19, 1978.) 